Review article

\title{
Impact of Maternal Periodontitis on Preterm Birth and Low Birth Weight in Babies: Results of a Scoping Review
}

Peace Uwambaye ${ }^{1}$, Cyprien Munyanshongore ${ }^{2}$, Stephen Rulisa ${ }^{3}$, Harlan Shiau 4 , Assuman Nuhu 5, Michael S. Kerr 6

${ }^{1}$ Department of Preventive \& Community Dentistry, School of Dentistry, College of Medicine and Health Sciences, University of Rwanda, Kigali, Rwanda

${ }^{2}$ Department of Community Health, School of Public Health, College of Medicine and Health Sciences, University of Rwanda, Kigali, Rwanda

${ }^{3}$ Department of Obstetrics and Gynecology, School of Medicine and Pharmacy, College of Medicine and Health Sciences, University of Rwanda, Kigali, Rwanda ${ }^{4}$ Department of Periodontology, University of Maryland, USA

${ }^{5}$ Department of Physiotherapy, School of Health Sciences, College of Medicine and Health Sciences, University of Rwanda, Kigali, Rwanda ${ }^{6}$ Arthur Labatt Family School of Nursing, University of Western Ontario, Canada

Corresponding author: Peace Uwambaye, Department of Preventive and Community Dentistry, School of Dentistry, College of Medicine and Health Sciences, University of Rwanda, Kigali, Rwanda. Email: upeace1602@gmail.com

\section{Abstract}

\section{Background}

Periodontitis has been documented as public health concern but its association with preterm and low birth weight remains uncertain, thus the objective of this scoping review is to summarize the most recent published evidence related to the impact of periodontitis on preterm birth and low birth weight in order to improve public awareness and to inform policies for oral health during pregnancy.

Methods

Hinari, PubMed, and Google Scholar were searched to acquire the published literature. The retrieved studies included cross-sectional, case control studies and randomized controlled trials with available full text published in English from 2008 to 2019.

\section{Results}

After combining the key words, 333 articles were identified with only 133 eligible 
articles published from 2008 to 2019. After reviewing the available 50 full text articles, duplicates were removed and 15 studies fully met the inclusion criteria. There were 13 articles that supported the association between maternal periodontitis and preterm low birth weight while 2 found no evidence to support the association.

\section{Conclusion}

The results of this scoping review contribute to an increasing body of evidence to support the hypothesis that maternal periodontal disease may be a risk factor for preterm delivery and low birth weight.

Rwanda J Med Health Sci 2020;3(3):372-386

Keywords: Periodontitis, Periodontal disease, Preterm birth, Low birth weight, pregnancy

\section{Background}

Periodontitis is a highly prevalent inflammatory and infectious disease of tooth-supporting tissues that can result in oral disability.[1] Periodontal diseases are commonly caused by gram-negative anaerobes that colonize the sub-gingival area. Periodontal diseases are reported to be the most common disease of mankind whereby severe periodontitis is the $6^{\text {th }}$ most prevalent disease worldwide.[2,3] The global burden of periodontitis is reported to have increased by $57.3 \%$ between 1990 and 2010.[3] A recent study on the global burden of diseases estimated that oral diseases affect 3.5 billion people worldwide and severe periodontitis was estimated to affect nearly $10 \%$ of the population.[4] Periodontitis, as a chronic non-communicable disease shares risk factors with the major non-communicable diseases (NCD's) that cause around two-thirds of deaths worldwide, such as heart disease, diabetes, cancer and chronic respiratory disease.
Periodontitis prevalence rates varied greatly across the European continent where by $13 \%$ was reported in Norway, $12 \%$ in the UK, $82 \%$ in Sweden, $25 \%$ in Switzerland and $80 \%$ in France.[5,6] The National Health and Nutrition Examination Survey (NHANES) conducted in the United states between 2009-2010, estimated prevalence rates of periodontitis in the U.S. population to be as high as $50 \%$,[7] while in Latin America, the prevalence of periodontitis was estimated to range between $40-80 \%$ over the period of 20 years between 2009-2010.[8] Shewale and colleagues in India reported the prevalence rate of periodontitis to be $85 \%$ in the general population and recommended the government as well as the dental council to develop and promote interventions in order to improve oral health and thus the quality of life.[10] Similarily, Bansal and colleagues found that $96.3 \%$ of the population in India had periodontal diseases.[12]

Periodontitis was reported to be very high in many African countries by 
Houshmound and co-authors. [1314] In East Africa, high prevalence of periodontitis has also been reported; in Uganda, Margret and colleagues conducted a study on determinants of periodontal health in pregnant women and the results showed that $67 \%$ of women presented with periodontal problems .[15] A high prevalence of periodontal diseases was also reported by Janviere and colleagues in Rwanda, [16] and Baelum et al in Kenya.[17]

Huck and colleagues have suggested that periodontitis might be linked to increased risk of preterm birth, but the evidence to support this association remains uncertain and debate about the association persists in the published literature. [18] Previous research has suggested that, periodontal infections can serve as a reservoir of inflammatory mediators, and thus may be a threat to the fetal-placental unit and therefore are associated with adverse pregnancy outcomes like preterm birth and low birth weight babies.[19] These inflamed periodontal tissues produce pro-inflammatory cytokines and host the bacteria that can cause inflammation once they get into the blood stream, where they are reported to possibly affect the fetus and result in low birth weight babies. [19] This connection is believed to originate with the deleterious effects of endotoxins released from the Gram-negative bacteria responsible for periodontitis. [19] The potential impact of periodontitis as a risk factor for low birth weight (LBW) requires further studies and also suggests a need for possible preventive measures for pregnant women as well as better collaboration between the obstetrical and dental professions.[20]

Given the controversy in the literature about the association of periodontitis with preterm low birth weight, a scoping review is an appropriate approach to assess the published evidence testing the association between maternal periodontitis and preterm birth and low birth weight in babies. Therefore, this scoping review was conducted to synthesize the evidence relating to the impact of periodontitis on preterm low birth weight. The results of this review could help to improve public awareness and to inform policies for oral health during pregnancy.

\section{Methods}

\section{Study design}

This scoping review was undertaken using the Arksey and O'Malley framework and was guided by The Preferred Reporting Items for Systematic Reviews and MetaAnalyses Extended for Scoping Reviews (PRISMA-ScR),[21] as discussed by Peterson and colleagues,[22] and recommended by Levac et al. [23] The study followed the stages of the Arksey and O'Malley framework which included: identifying the research question, (2) identifying relevant studies, (3) study selection, (4) charting the data and (5) collating, summarising and reporting the results .[21] The main strengths of a scoping review lie in its ability to examine a broader study area to identify research gaps and document on types of evidence that 
address and enlighten practice in the field under study. Therefore, the present scoping review is designed to synthesize the evidence on the impact of periodontitis on preterm low birth weight.

\section{Data sources and search strategy}

Electronic databases were searched for relevant articles. These databases included Hinari, PubMed and Google Scholar. The search strategies were developed and refined through the discussion among the authors. Retrieved articles were exported into Mendeley where duplicates were removed. The research team screened the titles and abstract independently from each other and any disagreement was resolved by consensus. The same process was used to screen the references. A thorough reading of the full text articles was performed by both reviewers for the papers selected from the initial title review.

Key search terms pertaining to the topics of periodontitis, preterm birth, low birth weight and risk factors were used for literature search. For example, in each data base the following key terms were used and combined as follows; (Periodontal disease OR periodontal diseases OR periodontitis) AND (Preterm birth OR Premature birth OR Gestational age OR Premature labor) AND (Low birth weight OR extremely low birth weight OR very low birth weight) AND ( risk factor OR causality OR etiology).

\section{Study selection}

Articles were included if they investigated periodontal disease in pregnancy in relation to gestational period and infant weight. The review was limited to case-control, crosssectional or randomized controlled trial designs conducted on human participants. Articles published between the periods of 2008-2019 and written in English were included. Reviews, case studies, editorials, magazine articles and commentaries were excluded.

\section{Data charting}

The reviewers used a consensus agreement approach to validate the data extraction form for consistency of the results from title screening and abstract review. [22] The data that were abstracted included the authors, years of publication, country, type of study, sample size, definition of periodontal disease used in the study. We also reported the main outcome variables and a summary of the final conclusions.

\section{Results}

\section{Description of studies}

The search from the different databases retrieved 320 articles from the initial search. These articles were screened based on the titles, years of publication and types of studies. Additional 13 articles were located from the reference scans of the screened articles. After the screening and reviewing the key search terms, 333 articles remainedof which 200 were deemed to be duplicates and thus were removed leaving 133 eligible articles. Of these 133 articles, a total of 93 articles did not meet the study inclusion criteria thus with a total of 40 articles were retained for 
full text screening.

Twenty-five

articles further removed for a variety reasons including missing information, thereby leaving 15 articles as shown in Figure 1.

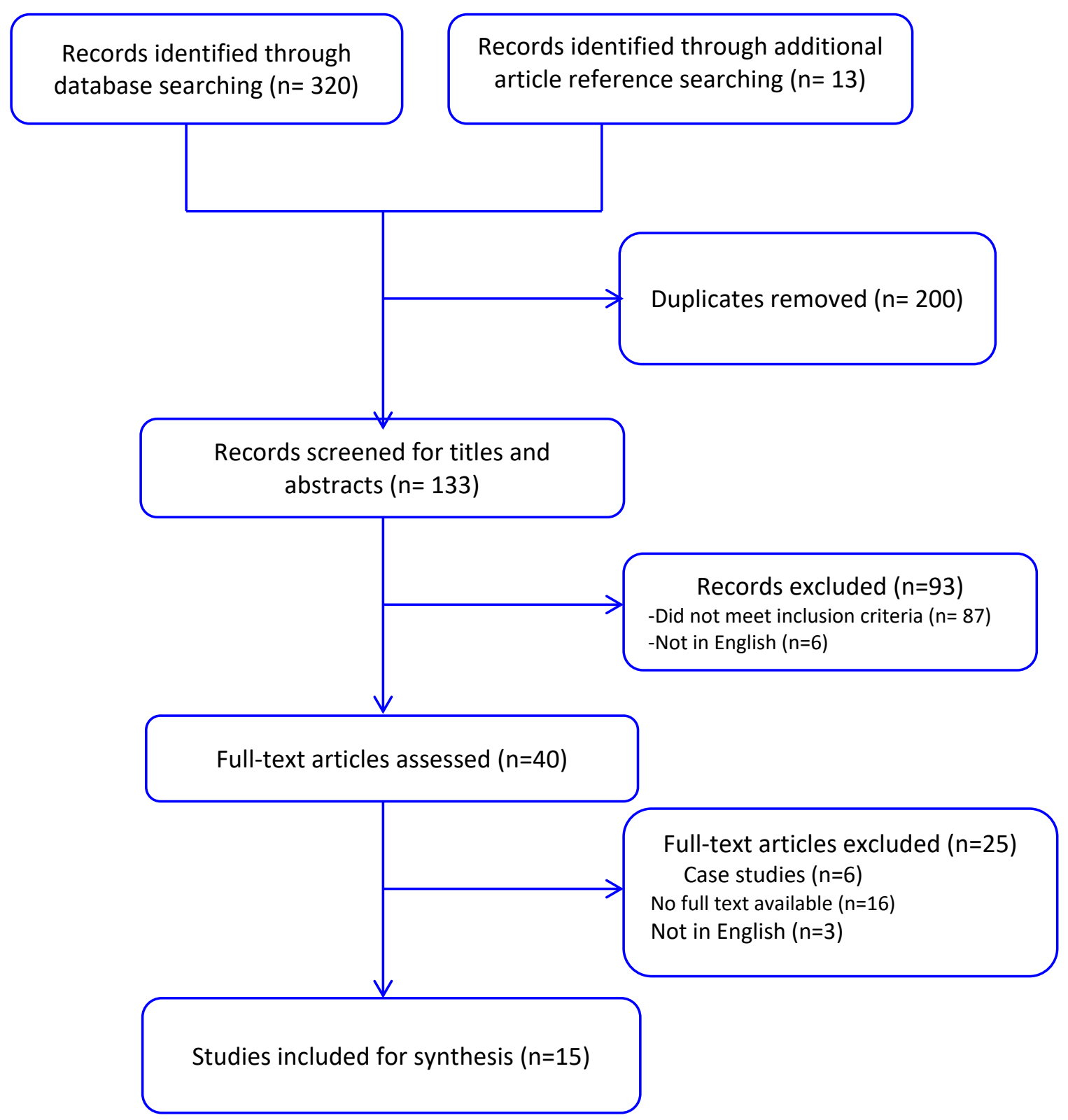

Figure 1. Flowchart for article selection 


\section{Overview of studies}

Among the 15 selected and included articles, there were 10 case control studies, three prospective cohort studies, one cross-sectional study and one randomized controlled trial, as shown in Table 1.

Table 1. Characteristics of the selected studies.

\begin{tabular}{|c|c|c|c|c|}
\hline $\begin{array}{l}\text { Authors, } \\
\text { publication } \\
\text { year and } \\
\text { Country }\end{array}$ & $\begin{array}{l}\text { Type of study } \\
\text { Sample size }\end{array}$ & $\begin{array}{l}\text { Periodontitis } \\
\text { definitions }\end{array}$ & $\begin{array}{l}\text { Outcome } \\
\text { variables }\end{array}$ & Conclusions \\
\hline $\begin{array}{l}\text { Wang } 2012 \\
\text { Taiwan }\end{array}$ & $\begin{array}{l}\text { Randomised } \\
\text { controlled trial } \\
N=211 \\
\mathrm{HG}=82 \\
\mathrm{GG}=67 \\
\mathrm{PG}=62\end{array}$ & $\begin{array}{l}\text { Gingival } \\
\text { bleeding }>5 \% \text {, } \\
\mathrm{CAL}>6, \mathrm{PD} \text { of } \\
5 \mathrm{~mm}\end{array}$ & $\begin{array}{l}\text { Gestational } \\
\text { age, birth } \\
\text { weight and } \\
\text { total maternal } \\
\text { weight gain } \\
\text { during } \\
\text { pregnancy }\end{array}$ & $\begin{array}{l}\text { The periodontitis group } \\
\text { women had a higher } \\
\text { frequency of preterm low } \\
\text { birth weight }(14.5 \%) \text { than } \\
\text { the healthy group } 7.3 \% \\
\text { and the difference was } \\
\text { significant } \\
\left(\mathrm{X}^{2}=15.345 ; \mathrm{p}=0.005\right)\end{array}$ \\
\hline $\begin{array}{l}\text { Rakot et al } \\
2010 \\
\text { Madagascar }\end{array}$ & $\begin{array}{l}\text { Prospective } \\
\text { cohort } \\
\mathrm{N}=204\end{array}$ & & $\begin{array}{l}\text { Preterm birth, } \\
\text { low } \\
\text { weight }\end{array}$ & $\begin{array}{l}\text { Periodontitis } \\
\text { significantly associated } \\
\text { with preterm birth } \\
(\mathrm{P}<0.001), \quad \text { low birth } \\
\text { weight }(\mathrm{P}<0.001) \text { and } \\
\text { preterm low birth weight } \\
(\mathrm{P}<0.001)\end{array}$ \\
\hline $\begin{array}{l}\text { Sindhu } \\
2009 \\
\text { USA }\end{array}$ & $\begin{array}{l}\text { Prospective } \\
\text { cohort } \\
\mathrm{N}=786\end{array}$ & $\begin{array}{l}\text { Not } \\
\text { mentioned }\end{array}$ & $\begin{array}{l}\text { Birth weight, } \\
\text { preterm birth }\end{array}$ & $\begin{array}{l}\text { This cohort study did not } \\
\text { support the association } \\
\text { between periodontitis } \\
\text { and preterm birth. }\end{array}$ \\
\hline $\begin{array}{l}\text { Lohana et al } \\
2016 \\
\text { India }\end{array}$ & $\begin{array}{l}\text { Prospective } \\
\text { cohort } \\
\mathrm{N}=300\end{array}$ & $\begin{array}{l}\text { Slight perio } \\
\text { CAL }=1-2 \mathrm{~mm} \\
\text { Moderate } \\
\text { perio CAL }=3 \text { - } \\
4 \mathrm{~mm} \\
\text { Severe perio } \\
\text { CAL } \geq 5 \mathrm{~mm}\end{array}$ & $\begin{array}{l}\text { Gestational } \\
\text { age, birth } \\
\text { weight, BMI }\end{array}$ & $\begin{array}{l}\text { As the level of periodontal } \\
\text { diseaser severity } \\
\text { increases, the proportion } \\
\text { of preterm delivery also } \\
\text { increases. }(p<0.005)\end{array}$ \\
\hline $\begin{array}{l}\text { Davenport } \\
2012 \\
\text { London, UK }\end{array}$ & $\begin{array}{l}\text { Case control } \\
236 \text { cases, and } \\
507 \text { controls }\end{array}$ & CPITN $=4 \mathrm{~mm}$ & $\begin{array}{l}\text { Birth weight, } \\
\text { Premature } \\
\text { deliveries }\end{array}$ & $\begin{array}{l}\text { There is no association } \\
\text { between periodontal } \\
\text { diseases and PTLBW }\end{array}$ \\
\hline
\end{tabular}




\begin{tabular}{|c|c|c|c|c|}
\hline $\begin{array}{l}\text { Grandi } \\
2010 \\
\text { Argentine }\end{array}$ & $\begin{array}{l}\text { Case control } \\
53 \text { cases } \\
79 \text { controls }\end{array}$ & $\begin{array}{l}\text { Bleeding } \\
\text { index of } 0-3 \text {, } \\
\mathrm{CAL}>1 \text {, } \\
\mathrm{PPD}>30 \% \text { of } \\
\text { involved sites }\end{array}$ & Preterm birth & $\begin{array}{l}\text { Bleeding index and } \\
\text { periodontal pockets } \\
\text { depths were associated } \\
\text { with preterm birth (odds } \\
\text { ratio }=4.19 ; 95 \% \text { CI: } 1.28 \\
-13.69, \mathrm{p}=0.018 \text { ) }\end{array}$ \\
\hline $\begin{array}{l}\text { Cruza et al. } \\
2013 \\
\text { Brazil }\end{array}$ & $\begin{array}{l}\text { Case control } \\
102 \text { cases } \\
200 \text { controls }\end{array}$ & $\begin{array}{l}\text { CAL } 4 \mathrm{~mm} \text { at } \\
\text { least } 4 \text { teeth }\end{array}$ & Birth weight & $\begin{array}{l}\text { Periodontal disease is a } \\
\text { risk factor for low birth } \\
\text { weight (LBW) }\end{array}$ \\
\hline $\begin{array}{l}\text { Satheesh } \\
2011 \\
\text { India }\end{array}$ & $\begin{array}{l}\text { Case Control } \\
52 \text { cases } \\
52 \text { controls }\end{array}$ & $\begin{array}{l}\mathrm{PD} \geq 4 \mathrm{~mm} \text {, } \\
\mathrm{CAL} \geq 3 \mathrm{~mm} \text { at } \\
\text { the same site } \\
\text { in atleast } 4 \\
\text { teeth }\end{array}$ & $\begin{array}{l}\text { Birth weight, } \\
\text { Preterm birth }\end{array}$ & $\begin{array}{l}\text { There is strong evidence } \\
\text { showing that maternal } \\
\text { periodontitis is an } \\
\text { independent risk factor } \\
\text { for preterm low birth } \\
\text { weight } \\
(P<0.001)\end{array}$ \\
\hline $\begin{array}{l}\text { Haerian et } \\
\text { al } 2013 \\
\text { IRAN }\end{array}$ & $\begin{array}{l}\text { Case control } \\
n=88 \\
44 \text { cases } \\
44 \text { controls }\end{array}$ & $\begin{array}{l}\text { CPITN grade } \\
\text { III and IV }\end{array}$ & Birth weight & $\begin{array}{l}\text { Mothers of LBW infants } \\
\text { had less healthy areas of } \\
\text { gingiva ( } \mathrm{p}=0.042) \text {, and } \\
\text { more deep pockets } \\
(\mathrm{p}=0.0006 \text {, Mann- } \\
\text { Whitney test). Maternal } \\
\text { periodontitis is therefore } \\
\text { a potential independent } \\
\text { risk factor for LBW. }\end{array}$ \\
\hline $\begin{array}{l}\text { Vettore et al } \\
2008 \\
\text { Brazil }\end{array}$ & $\begin{array}{l}\text { Case control } \\
\mathrm{N}=542 \\
\text { Cases } 149 \\
\text { Controls } 393\end{array}$ & & Birth weight & $\begin{array}{l}\text { Periodontitis is not a risk } \\
\text { factor for preterm low } \\
\text { birth weight. }\end{array}$ \\
\hline $\begin{array}{l}\text { Marakoglu } \\
\text { I. et al } 2008 \\
\text { Turkey }\end{array}$ & $\begin{array}{l}\text { Case control } \\
\mathrm{n}=48 \\
20 \text { cases } \\
28 \text { controls }\end{array}$ & $\begin{array}{l}3 \text { or more } \\
\text { sites with } \\
4 \mathrm{~mm} \text { or more } \\
\text { pocket depth, } \\
\text { bleeding on } \\
\text { probing, } \\
\text { alvealor bone } \\
\text { loss }\end{array}$ & $\begin{array}{l}\text { Preterm birth, } \\
\text { and low birth } \\
\text { weight }\end{array}$ & $\begin{array}{l}\text { The study results } \\
\text { indicated that } \\
\text { periodontitis is } \\
\text { independent risk factors } \\
\text { of a preterm low birth } \\
\text { weight. (OR=3.6; 95\% CI: } \\
1.06-12.18) \text {. }\end{array}$ \\
\hline $\begin{array}{l}\text { Karimi et al } \\
2016 \\
\text { Iran }\end{array}$ & $\begin{array}{l}\text { Case control } \\
\mathrm{N}=264 \\
132 \text { cases }\end{array}$ & CPITN & $\begin{array}{l}\begin{array}{l}\text { Preterm, and } \\
\text { low birth } \\
\text { weight }\end{array} \\
\end{array}$ & $\begin{array}{l}\text { Women with periodontal } \\
\text { diseases were } 10 \text { times } \\
\text { more likely to deliver low }\end{array}$ \\
\hline
\end{tabular}




\begin{tabular}{|c|c|c|c|c|}
\hline & 132 controls & & & $\begin{array}{l}\text { birth weight infants and } \\
8 \text { times more likely to } \\
\text { have premature infants } \\
\text { that women with no } \\
\text { periodontal diseases. }\end{array}$ \\
\hline $\begin{array}{l}\text { Kukkamalla } \\
\text { et al } 2014 \\
\text { India }\end{array}$ & $\begin{array}{l}\text { Case control } \\
\mathrm{N}=200 \\
100 \text { cases } \\
100 \text { controls }\end{array}$ & $\begin{array}{l}\text { Not } \\
\text { mentioned }\end{array}$ & $\begin{array}{l}\text { Preterm } \\
\text { delivery }\end{array}$ & $\begin{array}{l}\text { There was significant } \\
\text { association between } \\
\text { gingival inflammation, } \\
\text { probing depth to preterm } \\
\text { delivery and low birth } \\
\text { weight. }\end{array}$ \\
\hline $\begin{array}{l}\text { Khadem et } \\
\text { al } 2012 \\
\text { Iran }\end{array}$ & $\begin{array}{l}\text { Case control } \\
\mathrm{N}=70 \\
35 \text { cases } \\
35 \text { controls }\end{array}$ & $\begin{array}{l}\mathrm{CAL}>3 \mathrm{~mm} \\
\mathrm{PPD}>3 \mathrm{~mm}\end{array}$ & $\begin{array}{lr}\text { Preterm } & \text { birth, } \\
\text { low } & \text { birth } \\
\text { weight } & \end{array}$ & $\begin{array}{l}\text { Gum diseases was found } \\
\text { to be a risk factor for } \\
\text { preterm delivery. }\end{array}$ \\
\hline $\begin{array}{l}\text { MUWAZI et } \\
\text { al. } 2014 \\
\text { Uganda }\end{array}$ & $\begin{array}{l}\text { Cross } \\
\text { sectional } \\
\mathrm{N}=400\end{array}$ & $\begin{array}{l}\text { Bleeding on } \\
\text { probing, } \\
\text { probing } \\
\text { pocket depth, } \\
\text { calculus with } \\
\text { plaque } \\
\text { deposits and } \\
\text { gingival } \\
\text { recession }\end{array}$ & $\begin{array}{l}\text { Birth weight, } \\
\text { Gestational age }\end{array}$ & $\begin{array}{l}\text { Approximately } 26 \% \text { and } \\
29 \% \text { of the post-partum } \\
\text { mothers had gingival } \\
\text { bleeding and periodontal } \\
\text { pockets of } 4 \mathrm{~mm} \text { or above. } \\
\text { Gingival recession was } \\
\text { associated low birth } \\
\text { weight }(\mathrm{p}<0.005)\end{array}$ \\
\hline
\end{tabular}

$\mathrm{N}$ : B: List of abbreviations used in Table 1

CAL: Clinical attachment loss, PD: Probing depth, PTB: Preterm birth, LBW: Low birth weight, PTLBW: Preterm birth and low birth weight, CPITN: Community periodontal index of treatment need, PPD: Probing pocket depth, HG: Healthy group, GG: Gingiva group, PG: Periodontal group.

\section{Discussion}

The aim of the present review was to synthesize the evidence relating to the possible association between periodontitis and birth outcomes, including preterm delivery and low birth weight. This scoping review focused on the results of 15 different studies retrieved from the literature that were conducted to test these associations between periodontitis and birth outcomes. Despite the variability in the case definitions, 13 out of 15 included studies reported 
an association between periodontal disease and either prematurity, low birth weight or both outcomes. Out of the 13 studies that showed an association, some found an association between periodontal disease and low birth weight only $(n=5)$, some reported an association between periodontal disease and preterm birth $(n=3)$, and others reported association between periodontal disease and preterm low birth weight $(n=5)$.

Kastroit and colleagues reported that women with periodontal disease were 3.2 times more at risk $(\mathrm{OR}=3.2,95 \%$ CI 1.5-6.8) for delivering a low birth weight baby and 3.4 times more likely to deliver premature babies $(\mathrm{OR}=3.4,95 \%$ CI 1.6-7.3) than women without periodontal disease. [24] Also the findings from Karimi and co-authors reported that women with periodontal disease in their study were 10 times more likely to deliver low birth weight infants and 8 times more likely to deliver premature infants than women without periodontal disease.[25] The findings of this review are consistent with a recent systematic review of case-control studies only done by Teshome, which reported that periodontal disease may be a risk factor for preterm birth, low birth weight or preterm low birth weight and the odds ratio ranged from 24.[26] Studies show that the inflammatory cytokines such as tumor necrosis factor- alpha (TNF-a) and interleukin-6 (IL-6) which can reach high concentrations in periodontitis cases, stimulate increased prostaglandin production from the amnion and decidua, leading to the onset of preterm labor. [12] This is evidenced by the presence of increased cytokines and prostaglandin levels in preterm birth patients with no other infections like genitourinary tract infections. This supports the hypothesis that preterm low birth weight are associated with infections of unknown origin and possibly with periodontitis.[27-29]

One key challenge in reviewing the literature was dealing with the inconsistencies in the definitions of preterm birth, low birth weight and periodontitis used in the studies. Different authors used different definitions of the key terms under study. Almost all the authors considered bleeding on probing, pocket depth, calculus and clinical attachment loss (CAL) but the measurements for these parameters for defining periodontal disease varied depending on the authors. For example, some authors considered bleeding on probing, pocket depth and CAL, while others considered bleeding on probing, pocket depth, calculus and CAL and others only considered only pocket depth, and CAL.

The variability in these case definitions likely contributed to the heterogeneity of the study results and thus contributes to the overall uncertainty of the validity of the association. There is a need to have a calibrated definition of periodontal disease so that the researchers can have the same understanding of what is being studied. Also the variability in the results could also be impacted by differences in the study settings, the sample size, the 
duration of the study as well as the different periodontitis definitions.[2]

Some studies done in urban settings differed to studies done in rural settings because in urban settings, people may tend to have more advanced knowledge on oral health and better socio economic status both of which are known to have a positive influence on periodontal disease. For example the prospective study in this review done by Sindhu and colleagues, was conducted in an urban setting. This may have influenced the results of no association between periodontal disease and preterm low birth weight.

This is simply because the prevalence of periodontal disease tends to be lower and this may have reduced the study's statistical power.[29] This study by Sindhu was also testing for improvements in perinatal outcomes following periodontal treatment during pregnancy but it failed to show any association between periodontitis and preterm birth low birth weight . [29] This lack of association was in agreement with Bansal and colleagues who stated that providing periodontal treatment during pregnancy may be too late to reduce the local and systemic inflammations and may be ineffective in preventing the preterm birth.[30]

The case control study in Uganda conducted by Muwazi and colleagues also did not find any association between periodontitis and preterm birth and this could have been due to the use of small sample size in a short period of time that could have led to loss of some data resulting in inadequate statistical power and imprecise results.[31]

\section{Limitations of the study:}

The conclusions to be drawn from this scoping review are limited by the number and nature of the reviewed studies, because there was only one randomized controlled study and the majority were case control studies. While this review revealed inconsistencies regarding the association of periodontal disease and preterm low birth weight, there are different reasons among reviewed studies that may contribute to limited evidence.

The definitions of preterm birth and low birth weight were relatively consistent but the literature does not clearly point out the definition of periodontitis in periodontal research. A consensus on a definition of periodontits is important to optimize the interpretation, comparison, and validation of research data. Also clinical markers of periodontal disease, such as clinical attachment loss, bleeding on periodontal probing and periodontal pocket depth were defined considering different measurements.

Another potential reason for different findings among the included studies is the differences in the study settings. One of the studies that did not find any association between periodontal disease and preterm low birth weight in this review was conducted in urban setting which 
may have impacted the findings. [29] Finally, the study design was also among the factors for consideration as most of the studies were case control studies and these are limited in their ability to demonstrate causality. Lastly, it is also possible that some articles were missed in the review. Despite the above limitations, based on the fifteen articles reviewed, the scoping review provides evidence that periodontitis is associated with preterm birth and low birth weight outcomes.

\section{Conclusions}

In conclusion, the review has supported the existence of an association between maternal periodontitis and prematurity and low birth weight. The present scoping review highlights the need for further research that will enable the development of a screening tool to be used by nurses and midwives during antenatal consultations for early detection and referral of periodontitis during pregnancy. Also further research using more robust study designs, like controlled clinical trials should be done to confirm the impact of periodontitis on preterm low birth weight.

\section{Recommendations}

Although evidence supports this association between periodontitis and preterm birth and low birth weight, it is important in future research that scholars clearly specify exactly how they are defining their independent and dependent variables so that the inconsistencies observed in case definitions, study designs and findings can be minimised. Also more detailed and rigorous studies are needed with stronger, and ideally prospective randomized trial designs, using more calibrated (i.e. consistent) definitions of periodontal diseases. This more rigorous designs could more directly address the possible cause and effect relationship between periodontitis and preterm low birth weight.

\section{Implication of this study}

The results from this study may help to improve awareness about periodontitis and its possible association with preterm birth and low birth weight. It can also be used to inform the development of new public health policies relating to periodontal screening in the antenatal care package for early detection of periodontitis and to proactively promote periodontal health during pregnancy.

\section{Authors' contributions}

PU Searched for articles and participation in manuscript preparation.

PU and AN developed search strategies and refined through the discussion among the rest of the authors. CM, SR, MK and HS have made substantial contributions to the design and critical reading of manuscript. All authors read and revised critically and approved the final manuscript 


\section{Acknowledgements}

We acknowledge the University of Rwanda and Western University through Training Support Access Model Project (TSAM) for supporting this research.

\section{Conflict of interest}

All authors declared no conflict of interest and no competing financial interest.

\section{Funding}

Training Support Access Model (TSAM) project funded the study and it had no any other role in the design of the study, collection, analysis, interpretation of data or in writing the manuscript.

This article is published open access under the Creative Commons Attribution-NonCommercial NoDerivatives (CC BYNC-ND4.0). People can copy and redistribute the article only for noncommercial purposes and as long as they give appropriate credit to the authors. They cannot distribute any modified material obtained by remixing, transforming or building upon this article. See https://creativecommons.org/licenses/by-nc-nd/4.0/

\section{References}

1. Huck O, Tenenbaum $\mathrm{H}$, Davideau J-L, Huck O, Tenenbaum H, Davideau J-L. Relationship between Periodontal Diseases and Preterm Birth: Recent Epidemiological and Biological Data. J Pregnancy [Internet]. Hindawi Publishing Corporation; 2011 [cited 2016 Aug 27];2011:1-8. Available from:

http://www.hindawi.com/jou rnals/jp/2011/164654/

2. Wang Y-L, Liou J-D, Pan W-L. Association between maternal periodontal disease and preterm delivery and low birth weight. Taiwan $\mathrm{J}$ Obstet Gynecol. 2013;52:71-6.

3. Tonetti MS, Jepsen S, Jin L, Otomo-Corgel J. Impact of the global burden of periodontal diseases on health, nutrition and wellbeing of mankind: A call for global action. J Clin Periodontol [Internet]. 2017 [cited 2018 Jun 20];1-7. Available from: https://www.efp.org/publicati ons/Tonetti_et_al-2017-

Journal_of_Clinical_Periodont ology.pdf

4. Peres MA, Macpherson LMD, Weyant RJ, Daly B, Venturelli $\mathrm{R}$, Mathur MR, et al. Oral diseases: a global public health challenge. Lancet. Lancet Publishing Group; 2019. p. 249-60.

5. Wiley J. Global periodontal disease epidemiology. 2012;58:10-25.

6. Rose I, Smith D, Workshop W. Periodontal diseases in Europe. 2002;29:104-21.

7. Eke PI, Dye BA, Wei L, Thornton-Evans GO, Genco RJ. Prevalence of Periodontitis in Adults in the United States: 2009 and 2010. J Dent Res [Internet]. SAGE PublicationsSage CA: Los Angeles, CA; 2012 [cited 2018 Jun 21];91:914-20. Available 
from:

http://journals.sagepub.com/ doi/10.1177/0022034512457 373

8. Piscoya MDB de V, Ximenes RA de A, Silva GM da, Jamelli SR, Coutinho SB. Periodontitis-associated risk factors in pregnant women. Clinics (Sao Paulo) [Internet]. Hospital das Clinicas da Faculdade de Medicina da Universidade de Sao Paulo; 2012 [cited 2017 May 27];67:27-33. Available from: http://www.ncbi.nlm.nih.gov /pubmed/22249477

9. Shewale AH, Gattani DR, Bhatia N, Mahajan R, Saravanan SP. Prevalence of periodontal disease in the general population of India-A systematic review. J. Clin. Diagnostic Res. 2016.

10. Shewale AH, Gattani DR, Bhatia N, Mahajan R, Saravanan SP. Prevalence of periodontal disease in the general population of India-A systematic review. J. Clin. Diagnostic Res. 2016.

11. Bansal M, Mittal N, Singh TB. Assessment of the prevalence of periodontal diseases and treatment needs: A hospitalbased study. J Indian Soc Periodontol [Internet]. Medknow Publications and Media Pvt. Ltd.; 2015 [cited 2018 Jun 20];19:211-5. Available http:/ /www.ncbi.nlm.nih.gov /pubmed/26015675

12. Bansal M, Mittal N, Singh TB. Assessment of the prevalence of periodontal diseases and treatment needs: A hospitalbased study. J Indian Soc Periodontol [Internet]. Medknow Publications and Media Pvt. Ltd.; 2015 [cited 2018 Jun 21];19:211-5. Available from: http://www.ncbi.nlm.nih.gov /pubmed/26015675

13. Houshmand M, Holtfreter B, Berg MH, Schwahn C, Meisel $\mathrm{P}$, Biffar $\mathrm{R}$, et al. Refining definitions of periodontal disease and caries for prediction models of incident tooth loss. J Clin Periodontol. 2012;39:635-44.

14. Akpata ES. Oral health in Nigeria. Int Dent $J$ [Internet]. 2004 [cited 2018 Jun 21];54:361-6. Available from: http://www.who.int/oral_heal th/publications/orh_idj54_06 _akpata.pdf

15. Wandera M, Astrøm AN, Okullo I, Tumwine JK. Determinants of periodontal health in pregnant women and association with infants' anthropometric status: a prospective cohort study from Eastern Uganda. BMC Pregnancy Childbirth [Internet]. BioMed Central; 2012 [cited 2016 Aug 
29];12:90. Available from: http://www.ncbi.nlm.nih.gov / pubmed/22950749

16. Mutamuliza J, Rwema F, Rulisa S, Ntaganira J. Prevalence and Associated Risk Factors of Periodontal Disease among Adults Attending Dental Department in Rwanda Military Hospital (Rwanda): A Cross Sectional Study. Dent - Open J [Internet]. 2015;2:105-11. Available from: http:/ /openventio.org/Volume2 -Issue4/Prevalence-andAssociated-Risk-Factors-ofPeriodontal-Disease-amongAdults-Attending-DentalDepartment-in-RwandaMilitary-Hospital-Rwanda-ACross-Sectional-Study-DOJ-2120.pdf

17. Baelum. Periodontal diseases in adult Kenyans. - PubMed - NCBI [Internet]. [cited 2018 Jun 21]. Available from: https://www.ncbi.nlm.nih.gov /pubmed/3263399

18. Huck O, Tenenbaum H, Davideau J-L. Relationship between periodontal diseases and preterm birth: recent epidemiological and biological data. J Pregnancy [Internet]. Hindawi; 2011 [cited 2017 Oct 26];2011:164654. Available from:

http://www.ncbi.nlm.nih.gov / pubmed/22132334

19. Haerian-Ardakani A, Eslami Z, Rashidi-Meibodi F, Haerian A,
Dallalnejad P, Shekari M, et al. Relationship between maternal periodontal disease and low birth weight babies. Iran $\mathrm{J}$ Reprod Med [Internet]. Shahid Sadoughi University of Medical Sciences and Health Services; 2013 [cited 2017 Aug 8];11:625-30. Available from: http://www.ncbi.nlm.nih.gov / pubmed/24639799

20. Saini R, Saini S, Saini SR. Periodontitis: A risk for delivery of premature labor and low-birth-weight infants. J Nat Sci Biol Med [Internet]. Medknow Publications; 2010 [cited 2016 Aug 27];1:40-2. Available from: http://www.ncbi.nlm.nih.gov /pubmed/22096335

21. Arksey H, O’Malley L. Scoping studies: towards a methodological framework. Int $\mathrm{J}$ Soc Res Methodol [Internet]. Taylor and Francis Group Ltd ; 2005 [cited 2019 Jun 4];8:1932. Available from: http://www.tandfonline.com/ doi/abs/10.1080/136455703 2000119616

22. Peterson J, Pearce PF, Ferguson LA, Langford CA. Understanding scoping reviews: Definition, purpose, and process. J Am Assoc Nurse Pract. 2017;29:12-6.

23. Levac D, Colquhoun $\mathrm{H}$, O'Brien KK. Scoping studies: Advancing the methodology. Implement Sci. 2010;5:1-9. 
24. Meqa K, Dragidella F, Disha M, Sllamniku-Dalipi Z. The Association between Periodontal Disease and Preterm Low Birthweight in Kosovo. Acta Stomatol Croat. 2017;

25. Reza Karimi M, Hamissi JH, Naeini SR, Karimi M. The Relationship Between Maternal Periodontal Status of and Preterm and Low Birth Weight Infants in Iran: A Case Control Study. Glob J Health Sci [Internet]. Canadian Center of Science and Education; 2015 [cited 2019 Feb 25];8:184-8. Available from: http://www.ncbi.nlm.nih.gov /pubmed/26652090

26. Teshome A, Yitayeh A. Relationship between periodontal disease and preterm low birth weight: Systematic review. Pan Afr Med J. 2016;24:1-10.

27. Gandhimadhi D, Mythili R. Periodontal infection as a risk factor for preterm low birth weight. J Indian Soc Periodontol. Medknow; 2010;14:114.

28. Offenbacher S, Katz V, Fertik G, Collins J, Boyd D, Maynor $\mathrm{G}$, et al. Periodontal Infection as a Possible Risk Factor for Preterm Low Birth Weight. J
Periodontol [Internet]. 1996 [cited 2017 Oct 12];67:110313. Available from: http://www.joponline.org/doi /10.1902/jop.1996.67.10s.11 03

29. Srinivas SK, Parry S. Periodontal disease and pregnancy outcomes: time to move on? J Womens Health (Larchmt) [Internet]. Mary Ann Liebert, Inc.; 2012 [cited 2017 Aug 23];21:121-5. Available from:

http://www.ncbi.nlm.nih.gov /pubmed/21992584

30. Bansal M, Khatri M, Kumar A, Bhatia G. Relationship between maternal periodontal status and preterm low birth weight. Rev Obstet Gynecol [Internet]. MedReviews, LLC; 2013 [cited 2016 Aug 29];6:135-40. Available from: http://www.ncbi.nlm.nih.gov/p ubmed/24826203

31. Muwazi L, Rwenyonyi CM, Nkamba M, Kutesa A, Kagawa M, Mugyenyi G, et al. Periodontal conditions, low birth weight and preterm birth among postpartum mothers in two tertiary health facilities in Uganda. BMC Oral Health [Internet]. 2014 [cited 2018 Jun 23];14:42. Available from: http://www.ncbi.nlm.nih.gov/p ubmed/24773772 